\title{
PENTINGNYA KUALITAS E-SERVICE DAN CITRA PERUSAHAAN TERHADAP KEPUASAN KONSUMEN
}

Angelita Nauli Panggabean - 2301950881 - LB21

E-Business Strategy and Implementation

\section{Pendahuluan}

Perkembangan teknologi telah memberikan tantangan baru bagi banyak perusahaan. Perusahaan perlu berpikir dan mengetahui strategi yang cepat dan tepat demi tetap bertahan dan mampu bersaing di pasar. Salah satu startegi yang dapat dilakukan adalah dengan mengadopsi teknologi dalam proses bisnisnya. Penerapan teknologi akan memberikan dampak positif, baik bagi keberhasilan perusahaan maupun kemudahan bagi pelanggan. Teknologi secara nyata mampu memenuhi kebutuhan pelanggan. Hal ini akan menciptakan kemudahan dan kecepatan dalam proses transaksi, menghemat waktu dan biaya, serta menjangkau pasar yang lebih luas, baik nasional maupun internasional. Dengan begitu, perusahaan mulai berfokus pada penerapan aktivitas bisnis dengan teknologi, salah satunya melalui platform online.

Namun tidak hanya itu, sifat pelanggan yang berubah-ubah, sangat bervariasi, serta tidak dapat diprediksi pun menjadi tantangan bagi perusahaan itu sendiri. Perusahaan perlu terus berusaha untuk memberikan dan menjaga kepuasan pelanggan. Kualitas pelayanan dan citra perusahaan adalah kunci dan faktor penting yang dapat menentukan keberhasilan perusahaan dalam memberikan kepuasan pelanggan. Kualitas pelayanan dan citra perusahaan sering kali diabaikan oleh banyak perusahaan. Faktanya, kedua hal tersebut dapat memberikan peran dan dampak positif bagi keberlangsungan perusahaan dalam memenuhi kepuasan pelanggan. Dengan demikian, karya tulis ini bertujuan untuk mengetahui seberapa penting kualitas layanan dan citra perusahaan terhadap kepuasan pelanggan.

\section{Literature Review}

\section{Kualitas E-Service}

Kualitas pelayanan merupakan salah satu faktor pendorong pelanggan dalam menentukan keputusan untuk membeli suatu barang atau jasa (Hermawan, dkk. 2017). Menurut Kotler, layanan memiliki empat karakteristik atau sifat, antara lain Tidak berwujud (Intangible), merupakan layanan yang tidak dapat dirasakan, disentuh, dan dilihat oleh pelanggan sebelum membeli barang atau jasa, sehingga pelanggan harus membuat persepsi tentang layanan yang akan diterimanya nanti; Tidak dapat dipisahkan (Inseparability), merupakan layanan yang dijual terlebih dahulu sebelum diproduksi secara khusus oleh penjual. Dalam hal ini, konsumen sendiri terlibat langsung atau tidak langsung dalam proses produksi; Keragaman (Variability), merupakan layanan yang bersifat beragam; dan Tidak tahan lama atau mudah rusak (Perishability service), merupakan jasa yang memiliki karakteristik tidak tahan lama akibat sifatnya tidak berwujud fisik. 
E-Service atau Layanan Elektronik merupakan sebuah layanan yang berbeda dengan layanan biasanya, yakni layanan ini memanfaatkan teknologi informasi dan komunikasi atau dengan kata lain adalah layanan yang disediakan secara elektornik melalui internet. Layanan elektronik mencakup layanan transaksi pesanan online, layanan aplikasi, dan layanan apapun yang dapat diperoleh secara online. Kualitas layanan sendiri dibagi menjadi beberapa dimensi (Lasmy, dkk. 2019), antara lain reliability, yakni bagaimana perusahaan memberikan layanan yang dapat diandalkan dan terus menjaga kualitas yang berikan; responsiveness, yakni seberapa jauh perusahaan mampu dan siap dalam memberikan layanan yang dibutuhkan pelanggan; assurance, yakni seberapa jauh kualitas perusahaan, seperti pengetahuan, etika, serta profesionalisme dalam memberikan layanan kepada pelanggan; emphaty, yakni bagaimana tingkat kepedulian perusahaan terhadap pelanggan; dan tangible, yakni aspek psikologis dari pelayanan yang diberikan secara keseluruhan, seperti penampilan untuk kesan pertama, serta perlengkapan dan peralatan yang digunakan untuk mendukung pelayanan yang diberikan. Kotler juga menyebutkan bahwa terdapat tiga langkah yang efektif dalam menjaga mutu pelayanan, antara lain melakukan investasi dalam seleksi dan pelatihan karyawan yang baik; menyusun standarisasi terhadap proses pelaksanaan jasa dalam perusahaan secara keseluruhan; serta memantau tingkat kepuasan pelanggan, seperti melalui kotak saran, surveri konsumen, ataupun membuat hotline pesan dan pengaduan. Setiap perusahaan tentunya memiliki kualitas layanan yang berbeda-beda. Kualitas layanan kepada pelanggan dapat memberikan kepuasan dan mempertahankan pelanggan (Darmawan, dkk. 2017). Kualitas layanan yang baik dapat dijadikan faktor penting bagi perusahaan demi mempertahankan kepuasan pelanggan. Selain itu, kualitas layanan yang baik pun akan menarik pelanggan potensial. Berdasarkan studi (Darmawan, dkk. 2017), bahwa kualitas layanan memberikan dampak positif yang signifikan terhadap kepuasan pelanggan.

\section{Citra Perusahaan}

Sama halnya dengan kualitas layanan, citra perusahaan juga merupakan salah satu hal penting yang harus terus menerus dibangun dan dipelihara oleh perusahaan. Citra perusahaan diartikan sebagai gambaran, kesan, perasaan, ataupun persepsi konsumen terhadap perusahaan. Citra perusahaan sendiri mencakup mulai dari perasaan karyawan perusahaan itu sendiri, perspektif pelanggan, pemegang saham, masyarakat umum, media, hingga pihak luar yang bersangkutan dengan perusahaan. Berdasarkan penelitian (Darmawan, dkk. 2017), bahwa citra perusahaan memiliki hubungan yang positif dengan kepuasan pelanggan. Studi tersebut, didapat dari pengamatan pada tiga sektor, antara lain pendidikan, ritel, dan telekomunikasi. Citra perusahaan ini terbentuk dari kumpulan proses dimana pelanggan membandingkan berbagai atribut perusahaan (Hermawan, dkk. 2017). Atribut yang dimaksud adalah berasal dari fisik dan perilaku perusahaan, seperti nama bisnis, kualitas produk dan jasa, harga, arsitektur, dan juga kesan kualitas layanan yang diberikan perusahaan kepada pelanggan. Citra atau persepi terhadap perusahaan tentunya akan berbeda bagi setiap orang, walaupun dihadapkan oleh produk atau jasa 
yang sama. Penelitian lainnya (Rahyuda, dkk. 2017), memberikan bukti bahwa citra perusahaan memberikan pengaruh yang signifikan terhadap kepuasan pelanggan.

Terdapat lima dimensi dalam citra perusahaan (Lasmy, dkk. 2019) yaitu, corporate identity, yakni identitas suatu perusahaan yang membedakan dengan perusahaan sejenis lainnya; reputation, yakni karakter yang dimiliki perusahaan yang meliputi manajemen,kredibilitas, dan pelayanan yang bertujuan untuk memenuhi kebutuhan pelanggan; quality, yakni kualitas perusahaan yang mencakup kinerja perusahaan secara keseluruhan; physical quality, yakni berkaitan dengan lingkungan perusahaan secara nyata selama melakukan kegiatan operasional; dan interactive quality, yakni sebuah hubungan interaksi antara perusahaan dan pelanggan. Adapun beberapa langkah yang dapat diterapkan demi mencapai keberhasilan perusahaan dalam membentuk citra perusahaan yang baik. Langkah tersebut, antara lain memberikan kualitas pelayanan yang terbaik untuk pelanggan, bertanggung jawab dan peduli, baik terhadap pelanggan maupun lingkungan, serta menjunjung tinggi nilai kejujuran.

\section{Kepuasan Konsumen}

Menurut Philip Kotler dan Kevin Lane Keller, kepuasan konsumen merupakan perasaan, baik senang maupun kecewa yang dirasakan seseorang setelah membandingkan kinerja (hasil) produk atau jasa yang dipikirkan terhadap kinerja yang diharapkan. Kepuasan konsumen juga dapat didefinisikan sebagai reaksi atau respon emosional dari pengalaman yang dipengaruhi oleh baik buruknya kualitas layanan yang diberikan. Pengukuran kepuasan pelanggan adalah penting bagi perusahaan. Dengan mengetahui tingkat kepuasan pelanggan, perusahaan akan mendapatkan umpan balik atau masukkan yang berharga demi pengembangan dan penerapan strategi perusahaan dalam meningkatkan kepuasan pelanggan lebih lagi. Berdasarkan pengukuran Kotler, kepuasan pelanggan dapat meliputi, produk yang memberikan manfaat, komunikasi dengan pelanggan, pelayanan yang sesuai harapan, biaya yang dikeluarkan sesuai dengan yang diharapkan, dan kemudahan bertransaksi.

\section{Kesimpulan}

Berdasarkan penelitian (Lasmy, dkk. 2019), (Darmawan, dkk. 2017), (Hermawan, dkk. 2017), bahwa kualitas e-service dan citra perusahaan memiliki hubungan dan pengaruh positif signifikan terhadap kepuasan pelanggan. Dengan demikian, kualitas e-service dan citra perusahaan menjadi hal penting dalam memberikan kepuasan pelanggan. Penting bagi perusahaan untuk selalu memberikan pelayanan yang terbaik, dapat diandalkan, dan memenuhi kebutuhan pelanggan pelanggan. Selanjutnya, perusahaan juga penting untuk terus membentuk perilaku dan citra yang baik kepada semua pelanggannya, melalui produk dan jasa yang ditawarkan, kualitas layanan, harga, dan juga kesan kualitas layanan yang diberikan.

\section{Reference:}


1. E-service quality and corporate image on customer perception. Lasmy, Saroso, H., Syahchari, D. H., Sudrajat, D., \& Herlina, M. G. (2019). E-service quality and corporate image on customer perception. International Journal of Innovation, Creativity and Change, 10(8), 284-294

2. Rahyuda, I. K., \& Atmaja, N. P. C. D. (2017). The influence of price fairness, corporate image to the satisfaction and loyalty of Gia domestic flight users in Denpasar. EQUITY (Journal of Economics and Finance), 15 (3), 370- 395

3. Darmawan, D., Rahayu, M., \& Surjo H. (2017). The Effect of Service Quality, Customer Satisfaction and Corporate Image on Customer Loyalty in the banking sector in Indonesia. IOSR Journal of Business and Management (IOSR-JBM), 19 (11), 46-51

4. Hermawan, B., Salim, B., Asdar D., \& Annas, P. (2017). Effect of Service Quality and Price Perception on Corporate Image, Customer Satisfaction and Customer Loyalty among Mobile Telecommunication Services Provider. IRA-International Journal of Management \& Social Sciences, 8 (1), 62-73 